\title{
RELEVANT TECHNOLOGIES FOR DEVELOPING READINESS OF TEACHING STAFF FOR THE STANDARDIZATION OF JUNIOR SPECIALISTS' TRAINING
}

\author{
Tetyana Pashchenko', Andrii Kalenskyi², Nataliia Kalashnik ${ }^{3}$,
}

1 PhD in Pedagogy, Senior Researcher, Senior Research Fellow Laboratory of scientific and methodological support training of specialists in colleges and technical schools Institute of Vocational Education and Training of NAES of Ukraine, Kyiv http://orcid.org/0000-0002-7629-7870, e-mail: tantarena@ukr.net

2 Doctor of Education, Assistant Professor, Head of Laboratory of scientific and methodological support training of specialists in colleges and technical schools Institute of Vocational Education and Training of NAES of Ukraine, Kyiv http://orcid.org /0000-0001-9034-5042, e-mail: kaa_1959@ukr.net

3 Ph. D. in Pedagogy, Assistant Professor, Ukrainian language department, National Pirogov memorial medical university, Ukraine, Vinnytsia

https://orcid.org/0000-0001-5312-3280, e-mail: kalashnuknatalia@gmail.com

\begin{abstract}
:
Relevance: Professional training quality of prospective junior specialists mainly relies on teaching staff competence in professional training standards in colleges and technical schools.

Aim: The aim of this article is to determine the ways of implementing educational technologies to develop teaching staff competence in junior specialists' training standards.

Methods: A number of theoretical methods were used in this research including the analysis and the synthesis (to identify the current issue research level), summary (to make conclusions and recommendations).

Results: The implementation of this type of training system is based on educational methods including structural, logical, integrative, play-based, dialogic and other teaching techniques.

The authors briefly mention the educational technologies which are relevantly used to develop teaching staff competence in junior specialists' educational standards including training seminars, discussion seminars (group discussions), brainstorm, polylogues, positional discussions, training games (exercise games), staging (business simulation), complex action games (case-study method), contest games, projects (alternatively called "project management"), training, case problem solution, criteria kaleidoscope, talk-show.

Conclusions: Workshops, trainings, case methods, round tables and other educational technologies help achieve practical results in developing teaching staff competence in junior specialist training standards.
\end{abstract}

Keywords: teaching staff competence; junior specialists' educational standards; educational techniques.

Introduction: Teaching staff activity in professional education standards is one of the priority vectors of domestic educational system modernization.

The importance of special pre-higher education is based on involvement students into social and cultural professional activity, development their personality-forming ideals, values, beliefs and attitudes helping young people find own position in the world (Yershova, 2015).

Professional training quality of prospective junior specialists mainly relies on teaching staff competence in professional training standards in colleges and technical schools.

Sources. The issue is based on a wide number of aspects and vectors including the ways of training efficient competence in teaching activity (researched by Kolominskyi Y., Lysenko A., Luzan P., Mazukha D., Romanova G., Yaroshenko O.,), psychological aspects of teaching competence development (researched by Ball G., Vynogradova M., Gasparyan V., Dorokhina V., Karamushka L., Maztomazyan M., Molyako V., Ravykovych S., Rudyk P. and other scientists). 
It is important to point out that the research results offered by these scientists are insufficient to cover the issue of teaching staff competence in junior specialists' education standards.

The aim of this article is to determine the ways of implementing educational technologies to develop teaching staff competence in junior specialists' training standards.

Methods. A number of theoretical methods were used in this research including the analysis and the synthesis (to identify the current issue research level), summary (to make conclusions and recommendations).

Results and discussion. Special pre-higher education standards is expected to guarantee the unity of domestic learning environment, compatibility of basic educational plans, thus taking into consideration the personal abilities of all students. According to the Education Act adopted in Ukraine, one of the most essential conditions of modern quality education is to develop and implement a new generation of higher education standards comprising the rules of key competences of students, results of their learning, the whole education plan and other legally-approved components.

The implementation of competence approach is supported by educational methods and techniques helping students achieve estimated scientific results, enlisted in the educational standards (Luzan, 2018).

The aim of developing teaching staff competence in training standards of prospective junior specialists in colleges and technical schools is to implement motivational, cognitive, pragmatic and personal components studying the positive sides of educational concepts, ideas and technologies (Kalenskyi, 2019).

Teaching staff competence formation process in training standards of junior specialists in colleges and technical schools is supposed to be held both in basic educational establishments, training organizations, and to be closely connected with informal education.

Routine educational work is the key factor which favours teaching staff competence in training standards. Responsible approach to education plans, compatible with relevant teaching techniques helps motivate teachers to optimize their theoretical knowledge and practical skills.

Formation of teaching staff competence in junior specialists' training standards mainly relies on favourable educational environment in colleges and technical schools. This type of learning surrounding promotes self-development, helps teachers get familiar with best educational practices and advanced experience, latest know-hows and teaching techniques shared at pedagogical or psychological courses.
Formation of teachers' competences in colleges and technical schools is generally based on three involvement levels:

1. Research-to-practice conferences, educational seminars and councils, webinars.

2. Educational training, creative groups, advanced teaching experience and teaching art schools, seminars etc.

3. Self-education, research on individual educational issue(s) etc.

Teaching staff competence in junior specialists' standards is an integral personal feature which promotes self-discipline, boosts professional activity and helps achieve better performance.

Studying in appropriate educational organizations is expected to include extra training of teachers at seminars and courses with the purpose of optimization and sharing knowledge in junior specialists' training standards.

Informal education comprises lectures, roundtables, practical seminars, workshops and other forms of progressive special training aimed on raising teachers' readiness to professional activity in conditions of standards. Informal education is expected to include self-learning, studying regulatory documents, bibliography and e-resources such as topical portals, websites and net groups offering targeted aid to pedagogical employees enquiring information on education standards.

The methodical system of development of teaching staff competence in junior specialists' educational standards in colleges and technical schools mainly relies on learning methods including structural, logical, integration, play-based, dialogic and training techniques.

Learning performance motivation, modern learning environment, implementation of efficient learning methods, eventual self-control, achieving personal goals, active cognition interest, timeframes for learning and other factors prove this is a person-oriented learning technique.

Training workshops, self-learning development methods, contents-planning and academic progress assessment technologies are supposed to be implemented into learning schedule of educational institutions with the purpose of verifying the readiness of teaching staff to educational standards of junior specialists.

Training workshop as an educational technology makes it possible to use various methods and techniques in practice; as a model of gross activity it helps organize and conduct the entire learning process and create comfortable conditions for interaction and cooperation. 
Discussion workshop (group discussion) is held as an opportunity for dialogical communication among students. This type of discussion is a possibility for teachers to introduce and share their ideas as far as education standards are concerned, defend their views, rationally reject wrong decisions and offer better solutions to challenges. Personal knowledge and experience gained in process of self-education are essential conditions of building meaningful dialogues. Discussion workshop may also include elements of brainstorm and management decision simulations.

Brainstorm (brainstorming) is an efficient way of idea production used for finding solutions to different challenges. This technology is targeted on common intellectual activity on finding alternative ways to solve problems.

Using brainstorm technology to develop the competence in standards helps:

- establish connections between theoretical knowledge and practical assignments

- activate cognitive education activity

- create perception of information

- train skills to focus attention and exert efforts on solving practical assignments

- rain skills of collective intellectual activity (Strelnikiov V., Britchenko I., 2013).

"Aquarium" is an efficient exercise helping activate critical thinking. Participants are divided into two groups: the first group is expected to discuss topics; the second one is expected to supervise the process. Both groups of participants may change roles.

This exercise makes it possible to come to final decisions with regard on other colleagues' views, to reconsider own ideas after obtaining new information. This strategy is most useful on the way of building efficient interaction and meaningful communication among all participants. This is a reliable tool of teaching participants how to conduct debates.

Problematic/reflexive polylogue unites three or more participants in discussion representing different points of view. This is a reliable method developing teacher's competence in junior specialists' training standards introduced by interviews, discussions, conferences, disputes, management games and other forms. In comparison with dialogue, polylogue is a more complicated tool of education, since it has to consider bigger number of factors including personal characteristics of the involved parties. It is mainly used in group studies and person-oriented learning technology.

Positional discussion is an important method developing teacher's competence in junior specialists' training standards. It includes active interaction of all parties into finding optimal solutions, helps teachers replenish the standards database and makes it possible to openly express own ideas and attitudes to the topics under discussion.

This type of discussion in action expects teachers to be divided into three groups developing solution projects to educational challenges of standards. The third group is supposed to complete the synthesis and find the solution(s).

Play-based technologies help determine own activity contents, set goals, plan the stages of cognitive activity, choose topics, control and assess own work. Thus, implementation of play-based technologies helps form adequate motivation to activity, master psychological cognition method, develop social and communicative skills, activate standards process, aim on creative work.

Activity of all participants is based on creative use of games helping gain the essential amount of knowledge, master habits and train skills.

- Training games which contain problematic issue with definite solution-finding algorithm

- Management games (business simulation) help work out communicative skills in process of role-play

- Complex action games (solutions to case games) which include impromptu elements in action

- Contest games. Contest as a tuition method offers a text with detailed assignment description, to be fulfilled by two or three small groups of participants, ended by comparison of results. The most optimal result is chosen as the solution

- Game projection is conducted as a first stage of business game (imitation model of business project or plan, built during the course of the first stage). The main difference from the business game method is representation of how to imitate or to replay the process of object's creation or optimization (Honcharov, 2005)

- Training process, introduced as a method of making favourable conditions for finding solutions to own psychological problems, forming professional and interpersonal communication competence

- Case task (situational challenge). Participants are expected not only to analyse the current challenge, but to find relevant solution (Honcharov, Kostiukova ta Hubnitska, 2007).

- Criteria kaleidoscope. Participants are given cards depicting different choice criteria based on the current topic. During the following discussion participants are expected to point out the most important criteria and put the cards accordingly on the demonstration board (the more important the criteria are, the closer to the centre the cards are placed). The results are presented afterwards.

- Talk-show. This role game, based on TV talk 
shows helps participants to present scientific information, summarize the facts, make conclusions, establish self-control, promote self-esteem and reflexion.

So, the abovementioned techniques are based on synthetic-analytic activity and reflexive problem-solving followed by verbalization of intellectual processes (Bakhanov, 1999).

Implementation of competence-oriented junior specialists' training contents projection builds sufficient capacities for learning projection technology, play-based, coaching and case studies, and their practical usage in process of training junior specialists. It helps establish principles, find relevant approach to working out guidelines, possibly with IT-support throughout the entire course of junior specialists' training.

Workshops, coaching, case study method, roundtables and other educational technologies may help achieve estimated results in developing teaching staff competence in junior specialists' training standards.

Workshop technology is as active form of teacher's creative self-realization. It includes transferring experience by the means of both direct and commented demonstration of teaching techniques. A teacher is expected to be a professional mastering own creative pedagogical style and instructional tuition system.

During coaching sessions teachers are demonstrated different tests used as sample and algorithm to work out multilevel, valid and reliable students' academic progress assessment tests.

In order to guarantee instructionally correct realization of this educational technology, it is important to keep to the following (Sidorenko, 2002; Sysoyeva, 2011): permanent and stable groups, openness and readiness of all group members to interaction and communication, favourable psychological surrounding, keeping to the rules of teamwork and each period's structure, evaluation of coaching efficiency in terms of general conditions, psychic, creative and intellectual activity of its every participant.

The leading pedagogical experience points out the efficiency of case study technology in process of meeting targets set by development of teaching staff competence in junior specialists' training standards. This type of educational technology belong to the active tuition methods, its idea is to analyse situations, to discuss and to adopt decisions on certain professional issues (Goncharov, Kostyukova ta Gubnitska, 2007). Practical usage of case method helps built capacity of situational analysis, assess alternative decisions, pick up optimal solutions and realize its implementation.

Instructional and situational management games imitating professional creative pursuit are a reliable tool of developing skills of working out both educa- tional and academic progress assessment technologies.

The main task of every teacher is to train students how to turn efforts into activity. This task is greatly favoured by the technology of collective intellectual activity (CIA).

CIA technology is supported by interaction of all participants, connected with common cognitive interest. Positive results of collective pursuit are determined by organizing skills, intellectual abilities and inner motivation of every participant (Artiushina, 2013).

SMART technologies are widely used to develop teaching staff competence in junior specialists' training standards. SMART technologies open access to electronic resources on professional education standards with their theoretical aspects and interactive knowledge testing. The main advantage of SMART technologies is progressive optimization and simple access to making educational contents and single data repository (Lypska, 2018).

Personal component of teaching staff competence in junior specialists' training standards in colleges and technical schools comprises progressive academic support, contents optimization, replenishment and renovation, careful planning own educational activity and creative pursuit. Personal component helps keep to timeframes and deadlines, survey, analyse and summarize own academic results, implement novelty teaching techniques, improve own teaching style and reflexion skills, generate new ideas, choose optimal teaching contents, alter traditional teaching schemes, exercise alternative approach to problem solutions.

This component can be developed by the means of coaching sessions, workshops, implementation of creative problem-solving methods (inversion, empathy, morphological analysis, brainstorm, kaleidoscope of associations), synectics, fantastic ideas analysis and synthesis, heuristic questions and other methods.

Workshop "Building teaching staff competence in training standards in colleges and technical schools", discussion workshop "Structure and contents of modern educational standards: new updates", brainstorm "Idea and contents of competence", polylogue "Higher education standards", positional discussion "The main idea of competence-based educational programs", training games "Academic progress assessment tests", staging games, complex action games, contest games "How to pick up relevant educational content building definite competence in prospective junior specialists?", play-based projection "Education technology", training "What prevents implementation of educational standards?" and other events were conducted during the course of the experimental research 
titled "Methodical bases of junior specialists' training standards in colleges and technical schools".

Conclusions. The authors of this article have found out that the development of teaching staff competence in junior specialists' training standards is supposed to be held both in basic educational establishments, training organizations, and to be closely connected with informal education.

A number of teaching techniques including work- shops, trainings, case method, roundtables and other technologies may be helpful in development teaching staff competence in junior specialists' training standards.

The perspectives of further research in this area are supposed to be based on substantiation of recommendations of usage definite educational technologies developing teaching staff competence in junior specialists' training standards.

\section{List of references}

Артюшина, М.В., 2013. Використання технології колективної розумової діяльності у процесі навчання студентів економічного профілю. Науковий часопис Наиіонального педагогічного університету ім. М. П. Драгоманова. Серія 16. Творча особистість учителя: проблеми теорії і практики, 19 (29), с. 101-105.

Баханов, К. А., 1999. Що ж таке технологія навчання? Шлях освіти, 3, 24 с.

Гончаров, С. М., 2005. Науково-методичне забезпечення кредитно-модульної системи організації навчального процесу: монографія. Рівне: НУВГП.

Єршова, Л., 2015. Формування референтної особистості як проблема освітньої практики сучасної України. Вісник Черкаського національного університету. Педагогічні науки, 6 (339), с. 119-124.

Гончаров, С. М., Костюкова, Т. А. та Губницька, О. М., 2007. Креативні методи навчання в кредитно-модульній системі організаиії навчального прочесу: навч.-метод. посіб. Рівне: НУВГП.

Каленський, А. А., Лузан, П. Г., Ваніна, Н. В. та Пащенко Т. М., 2018. Стандартизаияія професійної освіти: теорія і практика; монографія. Житомир: «Полісся».

Липська, Л.В., 2018. Роль SMART-технологій у навчальному процесі професійних навчальних закладів. В: Адаптивні технології управління навчанням: матеріали четвертої міжнар. конф. Одеса, Україна, 24-26 Жовтень 2018, с. $15-19$.

Лузан, П.Г., Пащенко, Т.М., Ваніна, Н.М. та Колісник, Н.В., 2018. Стандартизація професійної освіти на основі компетентнісного підходу Science Rise, 5 (25), с. 32-35.

Сидоренко, Е.В., 2002. Тренинг коммуникативной компетентности в деловом взаимодействии. СПб.: Речь.

Сисоєва, С.О., 2011. Інтерактивні технологї̈ навчання дорослих: навчально-методичний посібник. НАПН України, Ін-т педагогічної освіти і освіти дорослих. Київ: ВД «ЕКМО».

Стрельніков, В. Ю. та Брітченко, І. Г., 2013. Сучасні технології навчання у вищій школі: модульний посібник для слухачів авторських курсів підвищення кваліфікації викладачів МІПК ПУЕТ, Полтава: ПУЕТ.

\section{Translated \& Transliterated}

Artyushyna, M.V., 2013. Vykorystannia tekhnolohii kolektyvnoi rozumovoi diialnosti u protsesi navchannia studentiv ekonomichnoho profiliu [Use of technology of collective mental activity in the process of education of students of economic profile]. Naukovyi chasopys Natsionalnoho pedahohichnoho universytetu im. M. P. Drahomanova. Seriia 16. Tvorcha osobystist uchytelia: problemy teorii i praktyky [Scientific journal of the National Pedagogical University. MP Dragomanov. Series 16. The creative personality of the teacher: problems of theory and practice], 19 (29), s. 101-105, [in Ukrainian].

Bakhanov, K. A., 1999. Shcho zh take tekhnolohiia navchannia? [What is learning technology?] Shliakh osvity [The path of education], 3, $24 \mathrm{~s}$, [in Ukrainian].

Honcharov, S. M., 2005. Naukovo-metodychne zabezpechennia kredytno-modulnoi systemy orhanizatsii navchalnoho protsesu: monohrafia [Scientific and methodological support of the credit-module system of organization of the educational process: monograph]. Rivne: NUVHP, [in Ukrainian].

Yershova, L., 2015. Formuvannia referentnoi osobystosti yak problema osvitnoi praktyky suchasnoi Ukrainy [Forming a reference person as a problem of educational practice in the modern Ukraine]. Visnyk Cherkaskoho natsionalnoho universytetu. Pedahohichni nauky [The Journal of Cherkasy National University. Pedagogy], 6 (339), s. 119-124, [in Ukrainian].

Honcharov, S. M., Kostiukova, T. A. ta Hubnytska, O. M., 2007. Kreatyvni metody navchannia v kredytno-modulnii systemi orhanizatsii navchalnoho protsessu [Creative methods of training in the credit-modular system of organization of educational process]: navch.-metod. posib. Rivne: NUVHP, [in Ukrainian].

Kalenskyi, A. A., Luzan, P. H., Vanina, N. V ta Pashchenko T. M., 2018. Standartyzatsiia profesiinoi osvity: teoriia $i$ praktyka: monohrafiia [Standards of Vocational Education: Theory and Practice: monograh]. Zhytomyr: «Polissia», [in Ukrainian].

Lypska, L.V., 2018. Rol SMART-tekhnolohii u navchalnomu protsesi profesiinykh navchalnykh zakladiv [The role of SMART-technologies in the educational process of professional educational institutions]. V: Adaptyvni tekhnolohii upravlinnia navchanniam: [Adaptive learning management technologies] materialy chetvertoi mizh nar. konf. Odesa, Ukraina, 24-26 Zhovten 2018, s. 15-19, [in Ukrainian].

Luzan, P.H., Pashchenko, T.M., Vanina, N.M. ta Kolisnyk, N.V., 2018. Standartyzatsiia profesiinoi osvity na osnovi kompetentnisnoho pidkhodu [Standards of a professional education according to a competency principle]. Science Rise, 5 (25), s. 32-35, [in Ukrainian]. 
Sydorenko, E.V., 2002. Trenynh kommunykatyvnoi kompetentnosty v delovom vzaymodeistvyy [Training of communicative competence in business interaction], SPb: Rech [in Russian].

Sysoieva, S.O., 2011. Interaktyvni tekhnolohii navchannia doroslykh [Interactive technologies for adult learning]: navchalno-metodychnyi posibnyk. NAPN Ukrainy, In-t pedahohichnoi osvity i osvity doroslykh. Kyiv: VD «EKMO» [in Ukrainian].

Strelnikov, V. Yu. ta Britchenko, I. H., 2013. Suchasni tekhnolohii navchannia u vyshchii shkoli [Modern technologies of education in high school]: modulnyi posibnyk dlia slukhachiv avtorskykh kursiv pidvyshchennia kvalifikatsii vykladachiv MIPK PUET, Poltava: PUET [in Ukrainian].

УДК 37.091.33:[377.091.12:005.963]:[006:377.36]

\section{Технології розвитку готовності педагогічних працівників до стандартизації підготовки молодших спеціалістів}

\section{Тетяна Пащенко ${ }^{1}$, Андрій Каленський², Наталія Калашнік3,}

1 кандидат педагогічних наук, старший науковий співробітник, старший науковий співробітник лабораторії науковометодичного супроводу підготовки фахівців у коледжах і технікумах Інституту професійно-технічної освіти НАПН України, м. Київ

2 доктор педагогічних наук, доцент, завідувач лабораторії науково-методичного супроводу підготовки фахівців у коледжах і технікумах Інститут професійно-технічної освіти НАПН України, м. Київ

3 кандидат педагогічних наук, доцент кафедри українознавства ВНМУ ім. М.І. Пирогова, м. Вінниця

\section{Реферат.}

Актуальність: якість професійної підготовки майбутніх молодших спеціалістів значною мірою визначається готовністю педагогічних працівників до стандартизації фахової освіти молодших спеціалістів у коледжах і технікумах.

Mema: з'ясувати особливості застосування педагогічних технологій для розвитку готовності педагогічних працівників до стандартизації підготовки молодших спеціалістів.

Методи: аналіз і синтез - з метою з'ясування стану та рівня розробленості досліджуваної проблеми; узагальнення - для формулювання висновків і рекомендацій щодо застосування технологій розвитку готовності викладачів до стандартизації підготовки молодших спеціалістів.

Результати. Основою реалізації методичної системи розвитку готовності педагогічних працівників до стандартизації підготовки молодших спеціалістів у коледжах і технікумах є застосування педагогічних технологій чи методик, серед яких виділяють: структурно-логічні, інтеграційні, ігрові, діалогові, тренінгові. Коротко охарактеризовані педагогічні технології, які доцільно застосовувати для розвитку готовності педагогічних працівників до стандартизації підготовки молодших спеціалістів: семінар-тренінг, семінар-дискусія (групова дискусія), мозковий штурм (мозкова атака, брейнстормінг), полілог, позиційна дискусія, ігри тренувального характеру (ігри-вправи), ігри-інсценівки (бізнес-симуляція), комплексні дієві ігри (розв’язання кейс-стаді), ігризмагання, ігрове проектування (інша назва ? управління проектами), тренінг, ситуація-проблема (ситуаційна задача), критеріальний калейдоскоп, ток-шоу.

Висновки: досягти реальних результатів розвитку готовності педагогічних працівників до стандартизації підготовки молодших спеціалістів допоможуть технології майстер-клас, тренінги, кейс-метод, «круглі столи» та інші технології навчання.

Ключові слова: готовність педагогічних працівників, стандартизація підготовки молодших спеціалістів, педагогічні технологї. 